\title{
Borders and Violence in Burundi: Regional Responses, Global Responsibilities
}

\author{
Niamh Gaynor \\ Dublin City University, Ireland
}

\begin{abstract}
Situated within the volatile Great Lakes region of Africa, Burundi has suffered decades of violence, displacement and re-displacement. As violence and insecurity continues, most notably following a third term bid in 2015 by the country's President, an estimated 400,000500,000 have been re-displaced, mostly across regional borders into neighbouring Tanzania, Rwanda, the Democratic Republic of the Congo and Uganda. This chapter exploresthe complex root causes of this ongoing violence, together with regional and global responses to this. Highlighting the role played by international actors and institutions in setting the ground for and sustaining the violence, it argues for a globalised politics of responsibility in responding to the ensuing crisis.
\end{abstract}

\section{Introduction}

Situated within the volatile Great Lakes region of Africa, Burundi has suffered decades of violence, displacement and re-displacement, most notably following the third-term bid in 2015 by the country's President,Pierre Nkurunzizi.The unrest preceding and following these elections has cost more than 1,000 lives and, in a country of just 10 million, an estimated 400,000-500,000 have been displaced and re-displaced over the last four years (UNHCR, 2019a). Clearly, efforts at peacebuilding and conflict transformation have failed. Examining the reasons for this, in this chapter I argue that the global aid community bears some responsibility for this failure through both its failed peacebuilding model and its implicit sanctioning of ongoing political intimidation and violence. Given this global complicity in fomenting and sustaining the current crisis, I argue for an attendant globalised politics of responsibility in responding to it. This includes lifting the glass ceiling on migration, thereby affording Burundians the opportunity and agency to seek employment elsewhere and assist their home communities directly. 
The chapter proceeds as follows. In the next section I set out the background to the ongoing violence and displacement in the country. Exploring the reasons for this, I move beyond simplistic ethnic explanations and highlight the fundamentally political nature of the unrest whereby, with implicit if not explicit Western collusion, the country's wealth has been and continues to be siphoned off by a political elite which is determined to remain in power at any cost. I then go on to examine regional policies and responses to the ensuing crisis. I highlight the detrimental effects of the lack of international support for regional initiatives which have left displaced households in limbo, living in deplorable conditions, with few opportunities for employment, and under threat of forced repatriation. Arguing for a global politics of responsibility in this regard, in the final section I develop this concept and flesh out what such a politics would entail.

\section{Violence and displacement in Burundi - some background}

Burundi is a small landlocked country in Central Africa. With a per capita Gross National Income (GNI) of just US\$702 and a Human Development Index ranking of 185 (out of 189 countries), it ranks as one of the poorest countries in the world (UNDP, 2018). It is also one of the most unequal, with a Gini coefficient of 33.3 per cent (UNDP, 2018). As the second most densely populated country in Africa, land stresses are significant and local conflicts over land are exacerbated by displaced people returning to find other families on their land (Kirchhof, 2009). Food insecurity is almost double the average in sub-Saharan Africa (SSA). According to the World Bank, some 1.8 million people are food insecure, with over half the children (six in ten) suffering from stunting in $2017^{\mathrm{i}}$.

\section{Ongoing violence and displacement}

Since attaining independence from Belgium in 1962, the country has been plagued by internal conflict and violence as different political actors mobilise for power and control over the country's resources. This has resulted in successive waves of displacement and re- 
displacement over the decades. In 1993, the country descended into a brutal civil war. Hundreds of thousands of Burundians were displaced, fleeing internally, to neighbouring countries and further afield. A peace agreement was signed in Arusha, Tanzania in 2000 but the war still dragged on as two rebel groups continued to fight. Elections were held in 2005 leading to a new power-sharing executive with ethnic quotas. It was not until 2009 however, that the war finally came to an end when members of the rebel groups were integrated into the army (Reyntjens, 2005). While there was hope and stability for a short time, with the 2000 peace negotiations internationally hailed as a 'success ' ${ }^{\text {ii }}$, the 2010 elections were marred by intimidation and violence by all contesting parties and unrest continued thereafter, with ongoing reports of political intimidation, repression and extra-judicial political assassinations (Gaynor, 2014a).

This violence escalated with the ruling party's announcement, on April 25 ${ }^{\text {th }}, 2015$, that the sitting President, Pierre Nkurunziza, would run for a third term in the forthcoming elections scheduled for June $26^{\text {th }}, 2015$, even though the constitution limits presidential tenure to two terms of office. Opposition parties and their adherents took to the streets. Security forces responded with force and the country once again descended into violent chaos(Wilén, 2016). When Nkurunziza won the disputed election ${ }^{\mathrm{iii}}$, violence once again escalated. There were numerous grenade attacks, including on civilian targets and police forces, with the violence reaching a peak on December $11^{\text {th }}$ with attacks on army barracks. The government crackdown that followed reportedly left 34 people dead in the streets of the capital, Bujumbura, in addition to those killed in the attacks (Jacobsen and Engell, 2018). Although 2016 saw a reduction in general violence towards civilians, repression, intimidation and political assassinations increased. More than 300,000 people were displaced and remained outside the country. During2017, 60,000 more people fled, bringing the total refugee population to over 400,000. Many of those fleeing were doing so for a second or third time, having been repatriated over ten years previously (Purdeková, 2017).

Although the Burundian government now insists that the instability is over, ordinary Burundians do not seem to agree and internal and external displacement continues (UNHCR, 2019a). Human Rights Watch (2019: 102), cataloguing a long list of human rights abuses, characterises the humanitarian situation as “dire”, while a recent report by the UN's 
Commission of Enquiry on Burundi (UNHCR, 2019b) notes that "Serious human rights violations, including crimes against humanity, have continued to take place since May 2018", with the main perpetrators being the ruling party's youth wing. In the run up to the elections in May 2020, there were reports that members of a newly formed opposition party had been arrested, beaten, disappeared and killed by the authorities and its affiliated youth militia ${ }^{\text {iv }}$. Meanwhile, as regional and international support for refugees dwindles, the UN Refugee agency claims that hundreds of new refugees are still fleeing from the country each month ${ }^{\mathrm{v}}$.

\section{The failure of peacebuilding and the global community}

It is clear therefore, that violence and unrest continues, and that there has been a profound failure in addressing the root causes of conflict despite the internationally acclaimed Peace and Reconciliation Agreement of 2000. There are two principal reasons for this failure. The first is an overly reductionist approach to the peacebuilding process which, evidence to the contrary, over-emphasised the ethnic dimensions of the violence over its political nature. While ethnic tensions have certainly been one of the key drivers of violence in the past (see Reyntjens, 2005; Daley, 2006; Lemarchand, 2007; Curtis, 2013), these are just one dimension of a much more complex political and social picture where inequality, political power and violence intersect, and where ethnic tensions can be, and have been, mobilised by a small group of powerful political elites to maintain their position of status and privilege (Ndikumana, 2005; Daley, 2006). Peter Uvin (2010: 170) describes it well. "In Burundi... high inequality was produced and maintained by the control of a small elite on the levers of the state (foremost the army). Corruption and rent-seeking, unequal access to education and privileged control over aid funds were the main pathways through which these elites managed to reproduce their advantages". Indeed, the Arusha Peace and Reconciliation Agreement begins by stating that the civil war was "fundamentally political, with extremely important ethnic dimensions; it stems from a struggle by the political class to accede to and/or remain in power" ${ }^{\text {'vi }}$. Yet, the agreement that followed focused largely on the ethnic dimension, and a culture of impunity for political elites from past and ongoing atrocities was allowed to develop (Lemarchand, 2007; Wilén, 2016). Wilén (2016: 70), pointing to the blind eye turned by global actors to the state's growing authoritarian tendencies, argues that "international actors have adopted a comfortable "laissez-faire" approach in the case of Burundi, characterized by a "good enough" peace. Relative stability has been exchanged for 
autocratic tendencies and an increasingly limited political space". This mirrors the attitude of global actors in neighbouring Rwanda where the state has grown increasingly authoritarian and repressive also (see Reyntjens, 2004; Beswick, 2010; Gaynor, 2016). As in the case of neighbouring Rwanda, the global community's need for a success story dominated international narratives and strategy around the Burundian process from 2000 forward. As Campbell (cited in Grauvogel, 2016: 8) notes:"in the wake of the 'unexpected success of Arusha', the international community, and especially Western donors, ignored the negative patterns that became visible from 2006 onwards."

The second reason for the failure in peacebuilding has been the international community's prioritisation of short-term relative stability over more long-term conflict transformation in its programming and support. A number of specific shortcomings can be identified. First, security sector reform, which has constituted a cornerstone of international peacebuilding since 2000, failed to prevent a renewed politicisation of the armed forces. In particular, and as seen elsewhere (see Kilroy, 2015), the 'R' of the DDR (disarmament, demobilisation, reintegration) process was never fully funded or implemented. The result is that, as Grauvogel (2016) argues, “...it is now easy for the government to remobilise the former rebels to carry out violent attacks on the opposition" which, as we have seen, is precisely what is happening today. Second, in relation to governance and democracy, the focus has been largely on high-level politics while ignoring local societal concerns. Both Curtis (2013) and Gaynor (2014b) have demonstrated the exclusionary nature of new governance arrangements, despite their inclusionary rhetoric.Citizens remain marginalised from local political fora and have little or no voice in the governance of their affairs. Third, the concerns of returning refugees post-war and pre-2015 were never met. While both the international community and the Burundian government have hailed the repatriation of large numbers, Purdekovà's research among displaced and re-displaced Burundians both highlights the cyclicality of this displacement and the fundamentally political motivations underpinning it. As she notes (2016: 3), one of the principal reasons for their displacement and determination not to return is the profound sense of distrust in the state and its institutions - "The picture that emerges is one of citizenship defined by broken political promises, unclear state motives, the lack of vertical accountability and resulting in feelings of distrust and deception". And finally,again as in the case of neighbouring Rwanda (see Hayman, 2011, Gaynor, 2016), the global 
community's need for a successful peacebuilding example dominated international narratives and strategy around the Burundian process from 2000 forward.

Thus, international and regional peacebuilding efforts, in prioritising stability over more long-term peace, failed to address the root causes of violence. This contributed to the development of a highly fragile post-war climate, one which stood ready to explode at any moment. As we will now see, when that moment came, international actors proved equally ineffective in rising to the resultant challenges, most notably in relation to support for the displaced, both regionally and internationally.

\section{Regional policies and responses}

As we have seen, ongoing political tensions and violence coupled with rising food insecurity has resulted in a deterioration of the humanitarian situation within Burundi and waves of displacement and re-displacement continue. Yet, according to the UNHCR, the Burundian refugee crisis was the least funded internationally in $2018^{\mathrm{vii}}$. This year (2019) a shortfall of

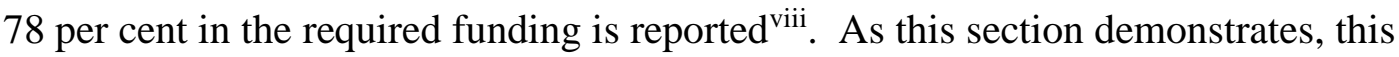
international failure to adequately respond to the political and humanitarian crisis is both irresponsible and unjust. As a political stalemate continues between regional governments and international agencies over who is responsible and who should take action, displaced households are left in limbo, living in deplorable conditions, with few opportunities for employment, and under a threat of forced repatriation.

\section{Migration figures - where are the displaced going?}

International migration figures for Burundi tell an interesting story. Numbers of migrants to non-African countries have traditionally been and remain extremely low in comparison to regional migration figures. The principal recipient countries internationally are Canada (which received 635 migrants in 2016), the United States (which received 415 migrants in 2016), Belgium (which received 333 migrants in 2016), France (which received 127 migrants in 2016), Australia (which received 120 migrants in 2016) and Sweden (which received 94 migrants in 2016) ${ }^{\mathrm{ix}}$. While the reasons for such low figures are of course complex, the 
restrictive migration policies in non-African countries coupled with the expense and danger of travel are undoubtedly key factors.

Regionally, migration figures from Burundi are much higher. Of the 400,000 plus Burundians who have fled the country since 2015, over half of these have fled to Tanzania, while Rwanda, the DRC, and Uganda have hosted 72,612, 45,447 and 42,334 respectively (UNHCR, 2019a). While these countries, most notably Tanzania, have traditionally been very generous in opening their borders to Burundians (see also below), the acute shortfall in international support coupled with domestic challenges means that borders are now closing and options to cross regional borders are becoming more and more difficult. According to the UNHCR, refugees are no longer being granted refugee status on a prima facie basis in Tanzania, Uganda, and DRC. (UNHCR, 2019a).

Internally within Burundi, many other people have been displaced, with people fleeing from urban to remote rural areas in the hills. Although it is hard to determine exactly how many people are internally displaced, the most recent figures (May 2019) from the International Organisation for Migration (IOM) estimate that there are 124,578 IDPs within the country ${ }^{\mathrm{x}}$.

\section{Living conditions of the displaced}

Whether internally displaced or settled in refugee camps across the border, living conditions for displaced individuals and households are reported to be extremely poor. According to the IOM, 57 per cent of internally displaced households have access to just one meal a day; 37 per cent have no access to clean drinking water; and 94 per cent of displaced people have no access to services following incidents of gender-based violence. In certain provinces, over 90 per cent of IDPs cannot afford health care; over 90 per cent have no access to a latrine; and over 50 per cent of children from IDP household do not attend school ${ }^{\mathrm{xi}}$.

Conditions in refugee camps across the border are also reported to be poor, with widespread overcrowding and cholera reported. According to Lukunka (2011), while in the refugee camps, displaced people are subject to attacks from roaming bandits. Incidents of violence 
against women are extremely high. Moreover, refugees in camps in Tanzania are not allowed to leave the camps in search of food or work and are forced to remain completely reliant on the limited services offered by camp authorities and international agencies such as the $\mathrm{UNHCR}^{\mathrm{xii}}$. The UNHCR (2019a) reports that 54 per cent of Burundian refugees are children. These face specific challenges including family separation, early marriage, teenage pregnancy, child neglect, child labour, domestic violence, sexual and gender-based violence, and psycho-social distress.

\section{Border and refugee policy in Tanzania}

As the above figures illustrate, Tanzania has long been extremely generous in opening its borders and providing refuge to Burundian displaced people. The 1972 genocide against the Hutu population produced one of Africa's most prolonged refugee situations as an estimated 275,000 fled. Although a number returned thereafter, 220,000 opted to stay. Under Tanzania's then 'Open Door' policy, these were allocated five hectares of land per family in three designated settlements in western Tanzania. By 1985, they were largely self-sufficient (Milner, 2014). More arrived later and were hosted in refugee camps in north-west Tanzania.

In 2007, the Tanzanian and Burundian governments in partnership with the UNHCR adopted an innovative strategy which offered a choice between repatriation and naturalisation to the 220,000 refugees living the in three settlements in Western Tanzania. The TANCOSS, as it was known (Tanzania Comprehensive Solutions Strategy), was an unprecedented intervention designed to offer stability and security to the long term displaced families and it attracted much international attention and support (Milner, 2014). Only 20 per cent of the 1972 Burundian refugees in Tanzania elected to go home. Many returned to find their land occupied after their long absence, with these secondary occupants having accrued certain legal rights. Land tenure conflicts are thus common among internally displaced and externally repatriated peoplein Burundi (Thomson, 2003).The vast majority of the displaced expressed a desire to remain in Tanzania where they were promised citizenship and relocation to new plots of land. 
While this strategy received widespread international acclaim, it was not without its shortcomings. Most notably, it fell victim to domestic opposition in relation to local integration and was never fully implemented (Milner, 2014). Plans for resettlement were abandoned and the newly naturalised migrants were permitted to remain in the areas of the settlements in which they had lived for the past four decades. As a result, it remains unclear when and how a transition to local governance will take place and what rights to the land the newly naturalized migrant in these settlements have (Kuch, 2018). As Kuch describes it, it is like being 'left in limbo'. As one migrant notes, "people here don't have ownership, you can be taken off your land at any time... It's like a marriage with no certificate"xiii.

The Tanzanian government has since pulled back further in its accommodation of migrants. In 2012, refugees were forcibly repatriated from a camp in Mtabila by firstly, having all services removed, then enduring a prohibition on all income-generating activities and finally,

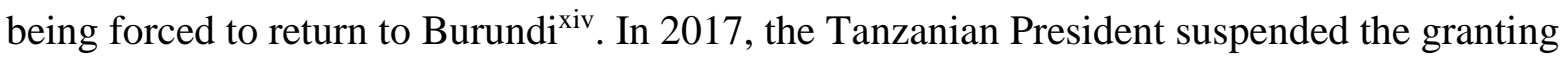
of citizenship to Burundian refugees ${ }^{\mathrm{xv}}$. And in January 2018, the Tanzanian government halted the naturalization of another group of more recently arrived Burundian refugees. It has since pulled out of the UN's Comprehensive Refugee Response Framework due to shortfalls in international funding ${ }^{\mathrm{xvi}}$. Little of the $\$ 103$ million earmarked for relocation and integration of naturalized refugees in the 2011-15 United Nations Development Assistant Plan has materialised, and a stalemate has developed between humanitarian organisations and the government with each accusing the other of broken promises. Residents of the settlements have been forced to live in uncertainty as they wait for citizenship documents and investment in infrastructure like access to clean water. Their situation has worsened considerably with the recent announcement of forced repatriation after October $1^{\text {st }}, 2019^{\mathrm{xvii}}$. While both the Tanzanian and Burundian government claim that conditions in Burundi have now stabilised, refugees fear otherwise. As one anonymous refugee, speaking to the BBC has noted, "It's very unfortunate. What have the international community or Tanzania done to stop Nkurunziza's government from persecuting people? There are killings, abductions and dead bodies found later. They are pushing us back to be killed".

While 'unfortunate' is certainly an understatement, the refugee's comment neatly encapsulates the international community's egregious abdication of responsibility in the face 
of ongoing violence and insecurity. As the promised resources and supports for displaced individuals and families have failed to materialise, with shortfalls of 78 per cent reported for 2018, it has largely been left to regional neighbours to deal with crisis. Yet, as we have seen in the preceding section, the international community bears a degree of responsibility for this crisis. It therefore should bear some of the responsibility for its resolution. This necessarily involves moving beyond the failed initiatives of the past which sought to contain rather than transform the underlying conditions of insecurity. It involves moving beyond piecemeal and uncertain funding supports in the region to a more globalised politics of responsibility. In the following section I develop this concept and flesh out in more detail what this might entail.

\section{From compassion to culpability: the case for a globalised politics of responsibility}

Promoting charity, assistance and support, the international humanitarian system is underpinned by ideals of compassion, sympathy and empathy for others. Confronted with distressing images of suffering and hardship, we are exhorted to dig deep and demonstrate compassion and charity. This is reflected, inter alia, in the identities and titles of a number of leading international non-governmental organisations (NGOs) such as Care International; Concern International; Caritas (meaning 'charity' in Greek and 'love for all' in Latin); Trócaire (meaning 'mercy' in Irish); and Save the Children. Yet, such framing negates the globalised nature of many humanitarian crises - both past and present, thereby negating the shared culpability of the global North in fomenting, sustaining and, in some instances, exacerbating these crises. The causes of specificcrises are often underdeveloped or, where they are, these are identified as being internal to Southern countries themselves, as opposed to being linked to broader structural constraints, or indeed, the failures or shortcomings of the global community and its interventions. The South is the problem, not the North. Moreover, the agency of Southern actors (state and civil society) in addressing these obstacles is largely negated as Southern actors are generally represented as constituting their principal architects. It therefore falls to Northern actors and institutions - i.e. the global aid community - to intervene and assist, thus laying the foundation and rationale for the global aid industry. The language of the aid community is replete with such ideology. To take an example, in a commentary on a World Bank's recent poverty report, Nirav Patel of the Brookings Institute notes 'the remarkable progress the world has achieved toward ending extreme poverty' 
(Patel, 2018: 20 - emphasis added), yet goes on to speak of 'sub-Saharan Africa's much slower fight against poverty'. Successes are attributed to the global community, while any failures are the global South's alone. This Northern saviour complex is not just damaging and demeaning to Southern actors and communities, it also masks the shortcomings and errors of Northern actors and institutions, negating their complicity in the production and reproduction of global inequality and unrest. In this section I outline four ways in which this complicity and culpability for the ongoing violence and unrest has played out in Burundi and its neighbouring region. I go on to make the case for a concomitant globalised politics of responsibility in addressing, in a sustainable and transformative way, both the fallout from and the roots of this violence.

First, colonial legacies continue to play a key role in contemporary politics within the region. Specifically, the ethnic tensions which have been identified as constituting one dimension of past and ongoing unrest are rooted in the 'divide and rule' tactics of former European colonising powers (Young, 1988). In addition, the neo-patrimonial spoils politics which underpinned both the President's third term bid in 2015 and the opposition's reaction to this, are also a direct legacy of the colonial administration's system of indirect rule in the region (Young, 1988). Burundi's violent, extractive 'big man's politics' was not born yesterday or in the recent past. Rather, it is the inevitable outcome of decades of violent, extractive colonial administration where the objective was neither equality or development, but suppression and exploitation (Ndikumana, 2005).

Second, although it is now sixty years since the colonial occupiers officially left the region, global extraction and exploitation continues apace. According to one account, (Honest Accounts, 2017: 7), although African countries receive around $\$ 19$ billion in aid each year, over three times that much ( $\$ 68$ billion) is taken out in capital flight, mainly by multinational companies (MNCs) deliberately misreporting the value of their imports or exports to reduce tax (Honest Accounts, 2017: 2). Moreover, MNCs legally extract \$32 billion each year, while illegal logging, trade in wildlife, and fishing account for $\$ 17$ billion, $\$ 10$ billion, and $\$ 1.7$ billion respectively (idem). While specific figures for particular countries are difficult to source, one study estimates that illicit outflows from Burundi amounted to $\$ 92$ million in 2015 (GFI, 2019: 31), while its resource rich neighbour, the Democratic Republic of the 
Congo (DRC), lost a total of $\$ 15.5$ billion in illicit capital flight from 1980 through to 2006 (GFI, 2008).

Third, although often celebrated in the global North for its achievements in reducing poverty in poorer countries, the empirical evidence on international aid's effectiveness in this regard is far more mixed, both in terms of quantities of aid dispensed and in terms of its effectiveness. Overall, volumes of aid to the global South are falling. They fell by 3 percent in 2018, with humanitarian aid falling by 8 percent $^{\text {xviii }}$. Aid flows to Burundi have followed a similar trend with the country's aid receipts amounting to just 12 per cent of its per capita GNI (\$ 290) in 2017. In contrast, neighbouring Rwanda, which has a per capita GNI of \$720, received aid amounting to 14 per cent of its GNI that same year, while Malawi, a country somewhat on a par with Burundi in terms of poverty (its per capita income was $\$ 320$ in 2017) received aid amounting to 25 per cent of its GNI that same year ${ }^{\mathrm{xix}}$. According to the UNHCR, the Burundian refugee crisis was the least funded internationally in 2018. In 2019, there was a shortfall of 78 percent in the required funding, with just US\$64 million of the $\$ 293$ million required secured (UNHCR, 2019b). More broadly, as we have already seen, aid that has been dispensed has proven less than effective as the global community has prioritised of short-term relative stability over more long-term conflict transformation in its programming and support. Although peace negotiations, held in Arusha, Tanzania, were widely declared a 'success' ${ }^{\mathrm{xx}}$, ongoing reports of political intimidation in the years that followed, and the overt insecurity and violence that has characterised the last four years (Human Rights Watch, 2019; UNHCR, 2019b), indicate a profound failure in aid efforts from 2000 forward.

And fourth, although Burundi ranks as one of the poorest countries in the world with its refugees receiving one of the lowest levels of support globally, Burundian migrants are also largely denied access to employment opportunities in the global North. During the last four years, of the 400,000 people who have fled the country, over half have been welcomed in the neighbouring country of Tanzania, while Rwanda, the Democratic Republic of the Congo (DRC), and Uganda have hosted 72,612, 45,447 and 42,334 respectively (UNHCR, 2019a). International migration figures are significantly lower, registering in the hundreds per annum in contrast to regional figures. This is in stark contrast to broader trends more globally. The World Bank reports that the worldwide number of international migrants has been increasing 
steadily from a level of 18 million in 2010 to 270 million in 2019 (2019: 9). Included in these figures are asylum seekers and refugees. By mid-2018, the global stock of refugees recorded by the UNHCR reached 20.2 million (Ibid). These migrants and refugees are estimated to have sent a combined \$698 billion back home in 2019 (World Bank, 2019: 9). This is over three times the volume of aid flows. As aid flows dwindle and stagnate, remittances are rising at a rapid rate in those countries who choose to welcome them.

While certainly not a panacea for poverty reduction and distributional justice, migrant remittances can and are assisting individuals and communities in real, tangible ways. They therefore represent another - potentially very significant - dimension of a global politics of responsibility. Remittances already play an important role in development within many Southern countries, amounting to over 25 per cent of some country's annual Gross Domestic Product (GDP) (for example, Haiti, Nepal, Tonga and Tajikstan) (World Bank, 2019: 3). As well as assisting families and communities to purchase necessities such as food, clothing and housing, these direct flows can also help in the development of livelihoods and businesses. Yet remittances to some of the world's poorest countries, notably those in SSA, remain at much lower level. At the high end, remittances to some SSA countries ${ }^{\mathrm{xxi}}$ amount to between 7 and 15 per cent GDP (World Bank, 2019: 23), yet some of the continent's poorest countries such as Burundi receive less than 1 per cent GDP ${ }^{\mathrm{xxii}}$, as the vast majority of Burundian migrants and refugees are forced to remain in neighbouring countries where employment opportunities are limited.

The reason for this is the failure of countries in the global North to embrace their global responsibilities. Despite European proclamations of a migration 'crisis' in the face of different conflicts worldwide, countries in the global South have historically hosted and continue to host by far the largest share of refugees. This was around 85 per cent of the global total in 2018 (UNHCR, 2018). Meanwhile, the approval rate for asylum applications in the European Union (EU) has been falling - from 46 per cent in 2017 to 37 per cent in 2018. With a total stock of over 870,000 pending asylum applications at the end of 2018 and also considering detected undocumented economic migrants, the World Bank (2019: 11) estimates that the number of migrants refused entry into EU countries in 2018 at over 6 million. The growing anti-immigration sentiment in many European countries is clearly 
having an influence. Although in December 2018, the UN General Assembly voted to formally adopt a Global Compact for Safe, Orderly, and Regular Migration as a step toward managing migration in a more humane and orderly manner, the withdrawal of several countries (mostly from within the EU) from this is indicative of heightened political sensitivities toward immigration ${ }^{\text {xxiii }}$. A glass ceiling exists and, as political sensitivities toward immigration heighten, the ceiling is turning to concrete. Such trends are indicative of an abrogation of culpability and responsibility on the part of the global community and undermine efforts towards building a global politics of responsibility.

There is, therefore, a fundamental hypocrisy at the heart of the global system. While the global community bears a significant degree of responsibility for this current crisis in Burundi and its neighbouring region, it is reluctant to share responsibility for its resolution. This is most starkly apparent in its lack of support for refugees in the region, leaving it to much poorer and crisis-ridden countries to bear the burden; and in its hardening stance on migration and the important remittance opportunities that this can offer. Global actors need to take responsibility for their role in the current, ongoing crisis. This responsibility needs to be matched with concrete support - both for people and communities displaced within the region, and for those making the difficult and challenging journey to the global North to earn money and assist their families and communities directly through remittances. While the instrumental reasons for such a politics of responsibility are clear - greater support should lead to greater stability in the region, in turn leading to less displacement and lower levels of hazardous, informal migration - the moral and political reasons override these. The global North has been and continues to be part of the problem. It therefore behoves it to be part of a just and sustainable solution.

\section{Conclusion: Regional responses yet global responsibilities}

The limitations and, at times, abject failure of the international aid model is exemplified by the case of Burundi where a combination of flawed programming and international inertia has left over 400,000 Burundians without homes, livelihoods, or any secure prospects for the 
future. International institutions and actors need to acknowledge that they have played a role in developing and sustaining the current crisis. They also need to accept that they have a responsibility to be part of a just and sustainable solution. This means going beyond erratic, though often well-meaning, displays of generosity and willingness to assist people once they stay at home, or in a neighbouring country, and embracing a global politics of responsibility which actively facilitates migrants and refugees taking the difficult and sometimes necessary choice to leave and assist their countries themselves. A glass ceiling exists and, as political sensitivities toward immigration heighten, the ceiling is turning to concrete. Yet, as the case of Burundi illustrates, given our culpability in sometimes heightening situations of insecurity and poverty, Northern countries have a responsibility to move beyond well-meaning, yet limited, inadequate and sometimes damaging aid interventions to more equitable and economically sustainable pathways to global peace and justice. 


\section{Bibliography}

Beswick, Danielle (2010) 'Managing Dissent in a Post-genocide Environment: The Challenge of Political Space in Rwanda',Development and Change41(2), 225-251.

Curtis, Devon (2013) 'The International Peacebuilding Paradox: Power Sharing and PostConflict Governance in Burundi', African Affairs, 112(446), 72-91.

Daley, Patricia (2006) 'Ethnicity and Political Violence in Africa: The Challenge to the Burundi state', Political Geography, 25(6), 657-679.

Gaynor, Niamh (2016) 'Beneath the veneer: decentralisation and postconflict reconstruction in Rwanda', Third World Thematics: A TWQ Journal, 1(6), 779-798.

Gaynor, Niamh (2014a) 'Bringing the Citizen Back In: Supporting Decentralisation in Fragile States - A View from Burundi', Development Policy Review, 32(2), 203-218.

Gaynor, Niamh (2014b) 'The Tyranny of Participation Revisited: International Support to Local Governance in Burundi', Community Development Journal, 49(2), 295-310.

Grauvogel, Julia (2016) 'Burundi after the 2015 elections: A Conference report', Africa Spectrum, 51(2), 3-14.

Hayman, Rachel (2011) 'Funding Fraud? Donors and Democracy in Rwanda', in Scott Straus and Lars Waldorf(eds), Remaking Rwanda: Statebuilding and Human Rights after Mass Violence,Madison, Wisconsin: University of Wisconsin Press,118-131.

Honest Accounts (2017) Honest Accounts: How the world profits from Africa's wealth, available https://www.globaljustice.org.uk/sites/default/files/files/resources/honest_accounts_2017_we b_final_updated.pdf, accessed $5^{\text {th }}$ October, 2019.

Human Rights Watch (2019) 'Burundi: Events of 2018' in World Report 2019,pp.101106.available athttps://www.hrw.org/sites/default/files/world_report_download/hrw_world_report_2019.pd f, accessed September 12 2019.

Global Financial Integrity (2019) 'Illicit Financial Flows to and from 148 Developing countries: 2006-

2015',https://secureservercdn.net/45.40.149.159/34n.8bd.myftpupload.com/wpcontent/uploads/2019/01/IFF-Report-2019_11.18.19.pdf?time=1580853010, Accessed February $5^{\text {th }}, 2020$.

Global Financial Integrity (2008) 'Capital Flight from the Democratic Republic of the Congo',https://secureservercdn.net/45.40.149.159/34n.8bd.myftpupload.com/wpcontent/uploads/2014/05/capital-flight-from-the-drc.pdf?time $=1580853010$, Accessed February $5^{\text {th }}, 2020$.

Kilroy, Walt (2015) Reintegration of Ex-combatants after Conflict: Participatory Approaches in Sierra Leone and Liberia, Basingstoke: Palgrave Macmillan. 
Kirchhof, Andreas (2009) 'Burundi: Seven years of refugee return', Forced Migration Review, 33(1), pp. 36-37.

Kuch, Amelia (2018) 'Land and exile: Revisiting the Case of Burundian Refugees in Tanzania', Critical African Studies, 10(1), 108-125.

Jacobsen, Katja Lindskov and Troels Gauslå Engell (2018) 'Conflict revention as pragmatic response to a twofold crisis: liberal interventionism and Burundi', International Affairs, 94(2), 363-380.

Lemarchand, René (2007) 'Consociationalism and Power Sharing in Africa: Rwanda, Burundi, and the Democratic Republic of the Congo', African Affairs,106(422), 1-20.

Lukunka, Barbra (2011) 'New Big Men: Refugee Emasculation as a Human Security Issue', International Migration, 50(5), 130-139.

Milner, James (2014) 'Can Global Refugee Policy Leverage Durable Solutions? Lessons from Tanzania's Naturalisation of Burundian Refugees’, Journal of Refugee Studies, 27(4), 553-573.

Ndikumana, Leonce (2005) 'Distributional Conflict: the State and Peace Building in Burundi', The Round Table, 94(381), 413-427.

Patel, N (2018) 'Figure of the Week: Understanding Poverty in Africa', 21 November, Brookings, available: https://www.brookings.edu/blog/africa-in-focus/2018/11/21/figure-ofthe-week-understanding-poverty-in-africa/, accessed $2^{\text {nd }}$ October, 2019.

Purdeková, Andrea (2017) “"Barahunga Amahoro - They are Fleeing Peace": The Politics of Displacement and Entrenchment in Post-War Burundi', Journal of Refugee Studies,80(1), 126.

Reyntjens, Filip (2004) 'Rwanda, Ten Years On: From Genocide to Dictatorship', African Affairs, 103(411), 177-210.

Reyntjens, Filip (2005) 'Burundi: A Peaceful Transition after a Decade of War?', African Affairs, 105(418), 117-135.

Thomson, Jessie (2009) 'Durable solutions for Burundian refugees in Tanzania', Forced Migration Review, 33(1), pp.35-36.

UNDP (United Nations Development Programme) (2018) Human Development Report, New York: UNDP.

UNHCR (United Nations High Commission for Refugees) (2018) Global Trends: Forced Displacement in 2017 https://www.unhcr.org/5b27be547.pdf (accessed 7 October 2019).

UNHCR (United Nations Human Rights Commission) (2019a) Regional Overview of the Burundian Refugee Population as of 31 July 2019, Geneva: UNHCR.

UNHCR (United Nations Human Rights Council) (2019b) Report of the Commission of Inquiry on Burundi, Available at https://undocs.org/en/A/HRC/42/49, accessed September $10^{\text {th }}, 2019$. 
Uvin, Peter (2010) 'Structural causes, development co-operation and conflict prevention in Burundi and Rwanda', Conflict, Security and Development, 10(1), 161-179.

Wilén, Nina (2016) 'The Rationales behind the EAC Members' Response to the Burundi Crisis', Georgetown Journal of International Affairs, 17(1), 69-78.

World Bank (2019) Migration and Remittances: Recent Developments and Outlook, Washington: World Bank.

Young, C. (1988) 'The AfricanColonialState and its Political Legacy', in D. Rothchild and N. Chazan (eds.), The Precarious Balance: State and Society in Africa, (Boulder, Westview, 1988), pp. $25-66$. 
'https://www.worldbank.org/en/country/burundi/overview, accessed September 20 th 2019.

ii See Susan Campbell 'What Burundi's Crisis says about UN's Capacity to Build Peace', Washington Post, May $18^{\text {th }}, 2015$,available https://www.washingtonpost.com/news/monkey-cage/wp/2015/05/18/what-burundiscrisis-says-about-un-capacity-to-build-peace/ (accessed 7 October 2019).

iii Following pressure from the opposition and the international community, the elections were postponed until July $21^{\text {st }}$. Sitting President Nkurunziza won with 69 per cent of the votes.

iv'Burundi 'at risk of fresh atrocities ahead of vote', Samba Cyuzuzo, BBC Great Lakes - September $5^{\text {th }}, 2019$, https://www.bbc.com/news/topics/ce1qrvlel07t/burundi, accessed September $9^{\text {th }}, 2019$; 'Fears of New

Atrocities Rise in Burundi as Nkurunziza Ratchets Up His Repression', Sam Mednick, Friday, Sept. 6, 2019 https://www.worldpoliticsreview.com/articles/28168/fears-of-new-atrocities-rise-in-burundi-as-nkurunzizaratchets-up-his-repression, accessed September $9^{\text {th }}$, 2019; 'Burundi: Campaigns Begin Amid Clampdown Media, Civil Society Muzzled; Opposition Targeted', https://www.hrw.org/news/2020/04/27/burundicampaigns-begin-amid-clampdown, accessed November $9^{\text {th }}$, 2020.. See also Human Rights Watch (2019).

"Tanzania to forcibly repatriate Burundi refugees' , Bernard Bankukira, BBC Great Lakes - August $28^{\text {th }}, 2019$, https://www.bbc.com/news/topics/ce1qrvlel07t/burundi, accessed September 9 $9^{\text {th }}, 2019$.

vi Article 4 of the Arusha Peace and Reconciliation Agreement, available at http://www.ucd.ie/ibis/filestore/Arusha\%20\%28Burundi\%29\%20.pdf, accessed October 13 ${ }^{\text {th }}, 2019$.

viihttps://www.unhcr.org/en-ie/burundi-situation.html, accessed September 12 2019.

viii Just US\$64 million of the \$293 million required has been secured

https://data2.unhcr.org/en/situations/burundil\# ga=2.219327001.1867504319.1567861407-

479138521.1563287126, accessed September 12 ${ }^{\text {th }}, 2019$.

ix Source: OECD International Migration Database - adapted from

https://stats.oecd.org/Index.aspx?DataSetCode=MIG, (accessed 12 October 2019)

xhttps://www.iom.int/countries/burundi, accessed 12 October, 2019.

xihttps://www.iom.int/countries/burundi, accessed 12 October, 2019.

xii Lunkunka, 2011; See also 'Things you should know about refugees in Tanzania',

https://www.nrc.no/perspectives/2019/6-things-you-should-know-about-refugees-in-tanzania/, accessed

September $16^{\text {th }}$, 2019; and 'Appalling conditions for Burundi and Congolese refugees in Tanzania',

https://www.dw.com/en/appalling-conditions-for-burundi-and-congolese-refugees-in-tanzania/a-44295204, accessed September $16^{\text {th }}, 2019$.

xiii Kuch, Amelia 'Lessons from Tanzania's historic bid to turn refugees to citizens', available at

https://www.newsdeeply.com/refugees/community/2018/02/22/lessons-from-tanzanias-historic-bid-to-turnrefugees-to-citizens, accessed September $12^{\text {th }}, 2019$.

xiv Van Laer (2018) '"There is pressure on us': Burundian Refugees in Tanzania pushed to Return',

https://africanarguments.org/2018/08/21/pressure-burundi-refugees-tanzania-pushed-return/, accessed

September $1^{\text {st }}, 2019$.

xv ibid

xviKuch, Amelia 'Lessons from Tanzania's historic bid to turn refugees to citizens', available at

https://www.newsdeeply.com/refugees/community/2018/02/22/lessons-from-tanzanias-historic-bid-to-turnrefugees-to-citizens, accessed September $12^{\text {th }}, 2019$.

xvii'Tanzania to forcibly repatriate Burundi refugees', Bernard Bankukira, BBC Great Lakes, August $28^{\text {th }}, 2019$, https://www.bbc.com/news/topics/ce1qrvlel07t/burundi, accessed September 9 $9^{\text {th }}, 2019$.

xviii OECD (2019) 'International Migration Database', available:

https://stats.oecd.org/Index.aspx?DataSetCode=MIG, accessed 15 $5^{\text {th }}$ September, 2019.

xix All figures are drawn from the OECD's interpretative statistical database which is available at

https://www.oecd.org/dac/stats/aid-at-a-glance.htm\#recipients, accessed September $19^{\text {th }}, 2019$.

${ }^{x x}$ Susan Campbell 'What Burundi's Crisis says about UN's Capacity to Build Peace', Washington Post, May $18^{\text {th }}$, 2015, available https://www.washingtonpost.com/news/monkey-cage/wp/2015/05/18/what-burundis-crisissays-about-un-capacity-to-build-peace/ (accessed 7 October 2019).

xxi The top five are The Gambia (at 15.3 per cent GDP); Liberia (at 12 percent); Senegal (9.1 per cent); Ghana

(7.3 percent) and Nigeria (6.1 per cent)

xxii Calculated by the author from the World Bank's database of development indicators - available

athttps://data.worldbank.org/indicator/BX.TRF.PWKR.DT.GD.ZS?locations=BI, accessed 12 October, 2019. 
xxiii See 'Who's afraid of the UN Global Compact for Migration?',Alan Desmond,

https://www.rte.ie/brainstorm/2018/1210/1016278-whos-afraid-of-the-un-global-compact-for-migration/, accessed September $28^{\text {th }}, 2019$. 